\title{
TESTING A MODEL OF DEVELOPING STUDENTS' PROFESSIONAL COMMUNICATION COMPETENCE WITHIN THE FRAMEWORK OF A SCIENTIFIC PROFESSIONAL PROJECT IN FOREIGN LANGUAGE IN A BLENDED LEARNING ENVIRONMENT
}

\author{
E.G. Korotkova, korotkovaeg@susu.ru, \\ I.A.Kolegova, kolegovaia@susu.ru \\ South Ural State University, Chelyabinsk, Russian Federation
}

\begin{abstract}
The article deals with testing a model of developing students' professional communication competence within the framework of a scientific professional project in foreign language in a blended learning environment. The necessity of this study is caused by the amendments made to the Law of the Russian Federation "About education" regarding application of e-learning, development of online courses. However, there is the lack of research on accompanying the development of students' competence of professional communication within the framework of scientific professional project (SPP) in a blended learning environment. That is why the aim of the paper is to test previously suggested model of developing students' professional communication competence within the framework of a scientific professional project in foreign language in a blended learning environment. In order to test the model we conducted pedagogical experiment with the following participants: 350 students of the South Ural State University, 2 lecturers, 5 Associate Professors and 2 Professors. The students were divided into four groups: 2 control (teaching in a traditional style) and 2 experimental (teaching according to the suggested model). For assessing students' communication competence we elaborated a special scale with three levels: low, middle and advanced. The results of the experiment indicate that the level of mastering the professional communication competence has increased in groups where the suggested model was implemented. It definitely proves that the implemented model will contribute to improving students' world academic reputation and formulating their research findings.
\end{abstract}

Keywords: blended learning, professional communication competence, scientific professional project, online courses.

\section{Introduction}

Nowadays Russian system of higher education enables students to be trained with common and professional competences, developed in the course of their studies. The most important of them in the sense of developing university relevance on the world's arena and increasing its criteria of academic reputation are professional competences in research fields $[13,16]$. For the most part, the competences refer to Master and $\mathrm{PhD}$ students. In spite of the fact that spheres of their professional activities may be different, they have to be ready for representing their research findings in the form of academic papers and presentations, communicating with the international academic society in foreign language (according to the Federal State Educational standards of higher professional education for different Masters' and $\mathrm{PhD}$ training directions) $[17,30]$.

Since the adoption of Federal law from 2/28/2012 \# 11-FL "About modification of the Law of the Russian Federation "About educa- tion" regarding application of e-learning and distance educational technologies", e-learning concept has become an integral component of educational process at higher schools in Russia [18]. Therefore, a number of questions have arisen to be solved. One of them is developing professional communication competence within the framework of a scientific professional project in foreign language in a blended learning environment. The model of developing this kind of competence was suggested by the authors of this article in an earlier publication and was applied in a traditional classroom teaching only [19, 29]. However, with the advent of compulsory online English courses as a support for classroom activities, it needs to be tested in a blend of face-to-face and computer mediated experiences. So, the goal of the paper is to represent the findings about testing the model of developing students' professional communication competence within the framework of a scientific professional project in foreign language in a blended learning environment. 


\section{Теория и методика профессионального образования}

\section{Literature review}

Blended learning

\section{for teaching foreign languages}

When considering the sphere of blended learning, such terms as e-learning and online learning are often used and should be defined correctly. Many well-known scholars have studied the phenomenon of blended learning: Boyle [4], Aspden and Helm [1], Hughes [15], Holley and Dobson [14], Chandra and Fisher [5], Gilbert [8], Lopez-Perez and Perez-Lopez [23], Boelens [3], Deegan [6], Gomes and Panchoo [12], Stockwell [27]. The term e-learning in the present paper is a generic expression for all learning involving the use of information technologies. Some disciplines seem to be studied within e-learning environment easier than others: management and law, mathematics and informatics, engineering and technology [20]. While the disciplines that deal with training professional communication skills (social sciences, linguistics) are impossible to be taught without traditional classroom training. Meanwhile, it is essential to meet the needs of all learners only in a classroom environment within a limited period of time: some students lack grammar or vocabulary training, others need more attention to listening or reading skills. At the same time, e-learning appears to be a necessary support for students' independent work for which twice more time is allocated than for in class activities in universities [28].

In this regard, for teaching foreign languages, a reasonably balanced educational environment is needed based on blended learning which is seen as a pedagogical model combining face-to-face classroom teaching and the innovative use of technologies. Therefore, one of the best decisions here is using online courses tailored specially for the purposes of a course. Just one of the debated questions set by scholars, how to blend e-learning, in what proportion with traditional teaching in class for different educational purposes and courses $[21,22]$.

\section{Scientific professional project (SPP)}

A scientific professional project is an overview of students' academic work in foreign language as an oral presentation or a research paper according to the generally accepted IMRaD structure $[10,24,25]$.

Within the framework of a scientific professional project, students' competence of professional communication is developed and threefold: the competence of communicating information (communicative competence), the competence of perceiving information (perception competence) and the competence of maintaining successful interaction (interactive competence) [2, 7, 26]. Within the interactive competence, students' abilities to maintain the feedback with the academic community, arouse debate and discussion on the subject presented in an academic paper or speech and to follow the principles of professional ethics are essential [9]. On the level of perception, the following criteria are valuable: the ability to understand professional jargon, terminology, arguments within a specific field of science both in oral and written forms, weigh claims in the balance, examine evidence on two sides in a case and judge, which is the weightier, reveal empathy and tolerance to the audience. The communicative competence suggests the ability to put forward strong arguments using correct grammatical structures, phonetics, professional jargon and terminology, make judgements when the evidence has dispelled reasonable doubt, persuade the academic community that the personal conclusion is safe and sound [11].

\section{Methods}

South Ural State University (national research university) was an experimental base of the study. The staff members who took part in round table discussions, Chair meetings, conducting practical English lessons and online instructors are 2 lecturers, 5 Associate Professors and 2 Professors. The pedagogical experiment covered $350 \mathrm{PhD}$ students of the first and second year in two experimental and two control groups, majoring in technical, chemical, social, exact sciences. It included three stages: summative, forming and controlling

At the summative stage, a complex of diagnostic measures was carried out in order to determine the initial level of professional communication competence development within the framework of SPP. This stage included filling in the forms by experts (English teachers) where they had to put the points for different criteria of professional communication competence development while observing the way students perform at presenting their preliminary research projects. An oral presentation and a poster were assessed together, and a special scale for that, with maximum 40 points, was elaborated (Table 1).

The second stage (forming) focuses on forming experiment where the model of developing 
students' professional communication competence within the framework of SPP was implemented and special skills necessary for revealing professional communication competence were developed both in classroom environment and through online courses worked out specially for the curriculum of $\mathrm{PhD}$ students.

Levels of professional communication

Table 1 competence development

Levels of professional communication competence development

\begin{tabular}{|c|c|c|}
\hline low & middle & advanced \\
\hline $0-13$ & $14-27$ & $28-40$ \\
\hline
\end{tabular}

The control groups were trained according to the curriculum both in classroom environment and through online courses "Developing Critical Reading Skills" and "Presenting at International Conferences" allocated on the university site by the Moodle platform. The students used online courses as a personal support when they stayed away from classes, needed to go over any topic or download supplementary materials.

The experimental groups were trained with syllabus, forms and methods selected to develop professional communication competence in a blended learning environment. For this purpose, active methods of organizing educational activity were used: presentations, case studies, games, role playing.

Presentations on the intermediate results of the research were prepared and demonstrated by students in class with follow up discussions, putting forward strong arguments, using professional jargon and terminology, making judgements on the discussed subject. Before classroom discussions, abstracts of the oral presentations were downloaded in a forum on an online course for peer reviewing, developing the ability to maintain the feedback from an academic community, arouse debate and discussion, weigh claims, and understand professional jargon and arguments within a specific field of science.

Clicker Cases, as one of the types of cases, were used to train academic vocabulary and professional terminology. The cases, depicting vocabulary units, were presented in class using a series of PowerPoint slides in parts, or stages. After each stage, students are asked to respond to questions (called "clicker questions") posed by the instructor to define vocabulary units. Before this in class activity, students study the vocabulary online. In this way, they learn to understand academic terminology in context.

One more type of cases - Interrupted Case was used to present a problem for students to solve in a progressive disclosure format, with the case given to students in parts to work in small groups and complete within a single class period. Students had to read an introduction from an oral presentation speech (a paper) and work in groups to propose a research question based on the issues from it. They developed a hypotheses and designed experiments to test it, which they then presented for the class to critique. After that, the instructor gave students information on how the actual authors of the paper had tackled the problem. After a description of the authors' methods, students were asked to predict the results, which they reported on when called on in class. The instructor then revealed the actual data, which students interpreted. Then the instructor revealed the authors' interpretations and conclusions. Before this class activity, specific vocabulary was pretaught through online courses. This format allowed students to practice all the aspects of professional communication competence.

For training communicative competence, Bingo and Scrabble vocabulary games were used in class to monitor pronunciation as compulsory. Online games such as Bingo, Scrabble, Crossword puzzles, ESL Games (for grammar topics) and training vocabulary and grammar exercises on online courses were optional after class activities.

To develop perception and communicative competence students did the following tasks on online course: reading academic papers on the topic of a research project and making up annotations with critical analysis on them; watching a series of Ted Talks videos with automatically checked comprehension tests. As a supplementary task, online gamification was used reading quizzes on the site www.eslgamesplus.com.

The method of role playing appeared to be the central one as it was used for acting out scientific conferences under the guidance of an instructor in class, simulating the conference scene as though it were real. Before the event, a serious preparation was done: the roles of organizing and program committees, a chairperson, conferees and a secretary were distributed among the students and the abstracts of the reports were reviewed on the forum of an online course. 


\section{Теория и методика профессионального образования}

\section{Results and discussion}

At the controlling stage, the authors identified the levels of students' professional communication competence development in experimental and control groups by analyzing the results from expert evaluation sheets. The sheets for assessing oral presentations contained four groups of criteria: interaction, perceptive, communicative (verbal) and communicative (nonverbal) (Table 2). For assessing a poster, three groups of criteria were used: content, text organization and visual support (Table 3). The experts completed the sheets while observing students' presenting at a training conference.

Then the data from the experimental and control groups were compared. The analysis allowed the authors to draw conclusions that the use of the model and specially selected content, forms and methods of education ensured the increase in development of students' professional communication competence.

The results from the table (Table 4) show that the students' level of professional communication competence in control and experimental groups was low before the experiment. After four months at the end of the two terms, the level of this competence changed into middle in both control groups (Figure 1). It can be accounted for a good support of online courses tailored specially for the curriculum of $\mathrm{PhD}$ students in English. Though they were not compulsory for students who attended classes, the courses were popular among students as they used them for training their weak points and downloading educational materials.

After the experiment the level of students' professional communication competence was increased up to advanced by $40,75 \%$ and by $48,5 \%$ in Groups \#1 and \#2 correspondingly. Interestingly, we discovered that the students from both experimental groups started to pay their attention not only to their verbal communication but also to the nonverbal signals, started using the techniques of arousing feedback (short story telling, focusing attention on three main aspects, questions to the audience, visualizing) They started to interact with their colleagues more effectively and control their nonverbal behavior.

Expert sheet for evaluating an oral presentation

Oral explanation of a poster. Criteria for assessment (20 points)

Competences of professional communication

\begin{tabular}{|c|c|}
\hline & Score \\
\hline \multicolumn{2}{|l|}{ Interaction component } \\
\hline Ability to arouse interest to the report: questions, comments from the peers & 1 \\
\hline \multicolumn{2}{|l|}{ Perceptive component } \\
\hline Understanding the contents of the reports and posters of the peers (questions, opinions, comments) & 1 \\
\hline Understanding the peers' questions (answers to the questions on the report and poster & 1 \\
\hline \multicolumn{2}{|l|}{ Communicative component (verbal) } \\
\hline $\begin{array}{l}\text { Grammatical and lexical range and accuracy - specific language structures and vocabulary } \\
\text { (see the table below) }\end{array}$ & 5 \\
\hline Pronunciation & 1 \\
\hline Cohesion and coherence (using linking words) & 1 \\
\hline Fluency & 1 \\
\hline Logical flow & 1 \\
\hline Use of professional terminology & 1 \\
\hline Validity of the statements (giving reasons, premises) & 1 \\
\hline Conciseness & 1 \\
\hline \multicolumn{2}{|l|}{ Communicative component (non verbal) } \\
\hline Eye contact & 1 \\
\hline $\begin{array}{l}\text { Gestures relevant to the situation (restrained, used to emphasize points, out of your pockets, without } \\
\text { folding and wringing) }\end{array}$ & 1 \\
\hline Posture (relaxed, straight, natural, feet apart, shoulders squared, facing the audience) & 1 \\
\hline Facial expression (calm, natural, a bit smiling) & 1 \\
\hline Dress code (conservative, business like) & 1 \\
\hline Итого: & 20 \\
\hline
\end{tabular}


Expert sheet for evaluating a poster

Poster evaluation chart (20 points)

\begin{tabular}{|l|c|}
\hline \multicolumn{1}{|c|}{ Content assessment } & Score \\
\hline \multicolumn{1}{|c|}{} \\
\hline Introduction & 1 \\
\hline Gives a clear statement of a study & 1 \\
\hline Provides synopsis of the relevant research projects & 1 \\
\hline Methods & 1 \\
\hline Gives a description of procedures and measurements & 1 \\
\hline Gives an overview of the techniques used for data analysis & 1 \\
\hline Results & 1 \\
\hline Gives an account of the major finding of the project & 1 \\
\hline Provides graphical aids (tables, figures, graphs, charts, etc.) & 1 \\
\hline Discussion & 1 \\
\hline Makes clear, accurate and well-articulated conclusions & \\
\hline Suggests practical application of the study results & 1 \\
\hline Relates finding to the ongoing research & 4 \\
\hline Considers areas for prospective studies & \multicolumn{1}{|c|}{ Poster section } \\
\hline Text organization & (1 per each section) \\
\hline Sequential, logically progressing information & 4 \\
\hline $\begin{array}{l}\text { Complies with the format requirements in each section: Introduction, Methods, Results, } \\
\text { Discussion (using bullet points) }\end{array}$ & (1 per each section) \\
\hline $\begin{array}{l}\text { Sufficient linguistic competence of each section: Introduction, Methods, Results, } \\
\text { Discussion (using academic collocations, terminology relevant to the subject) }\end{array}$ \\
\hline Visual support & 1 \\
\hline Conspicuous title and section headings, easily readable text & 20 \\
\hline Total score: & \\
\hline
\end{tabular}

\section{Experimental results}

Table 4

\begin{tabular}{|c|c|c|c|c|c|c|c|c|}
\hline $\begin{array}{c}\text { Professional } \\
\text { communication } \\
\text { competence } \\
\text { (simple average } \\
\text { value) }\end{array}$ & \multicolumn{2}{|c|}{ Control group \#1 } & \multicolumn{2}{|c|}{ Control group \#2 } & \multicolumn{2}{|c|}{ Experimental group \#1 } & \multicolumn{2}{|c|}{ Experimental group \#2 } \\
\cline { 2 - 9 } & before & after & before & after & before & after & before & after \\
\hline Total (max 40) & 19,1 & 23,1 & 17,4 & 18,08 & 15,2 & 28,5 & 17,1 & 29,5 \\
\hline
\end{tabular}

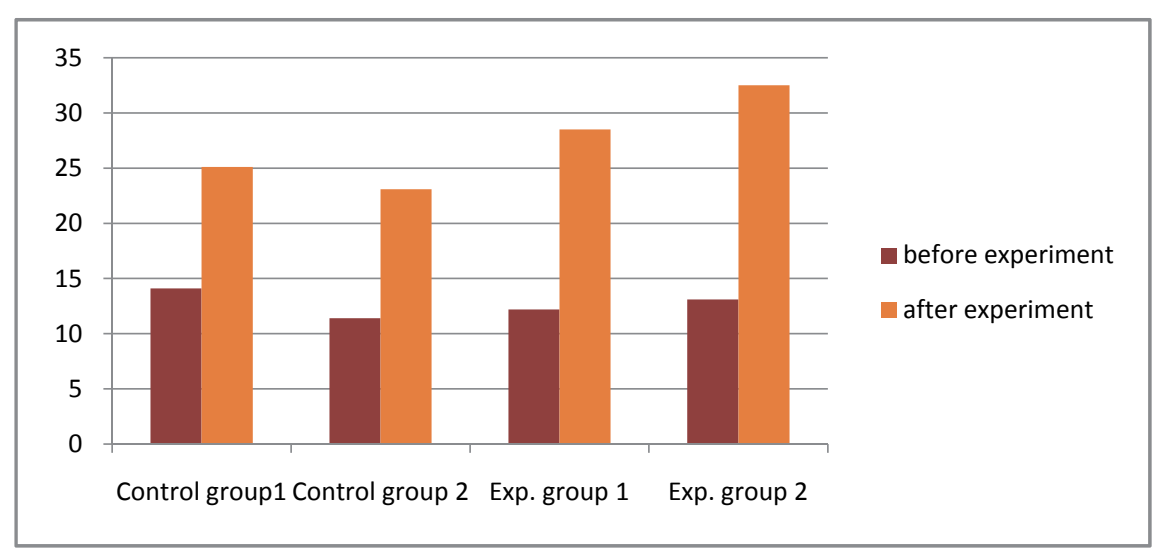

Figure 1. The level of professional communication competence development before and after the experiment 


\section{Теория и методика профессионального образования}

\section{Conclusion}

Thus, we tested a model of pedagogical accompaniment of developing students' professional communication competence within the framework of SPP in foreign language in a blended learning environment. The results of it proved to be successful in terms of students' presenting at training academic conferences and their readiness for presenting at real conferences. These results will definitely contribute to improving students' outstanding international academic reputation and formulating their breakthrough research findings.

\section{References}

1. Aspden L., Helm P. Making the Connection in a Blended Learning Environment. Educational Media International, 2004, no. 41 (3), pp. 245-252. DOI: $10.1080 /$ 09523980410001680851

2. Barushnikova E.N., Klepach E.V., Krass N.A. Rechevaya kul'tura molodogo spetsialista [Speech Culture of a Young Specialist]. Moscow, Flinta Publ., Nauka Publ., 2005. 224 p.

3. Boelens R., VanLaer S., DeWever B., Elen J. Smeshannoe obuchenie $v$ obrazovanii vzroslykh: $k$ opredeleniyu smeshannogo obucheniya [Blended Learning in Adult Education: Towards a Definition of Blended Learning]. Available at: https://biblio.ugent.be/publication/ 6905076 (accessed 12.12.2018).

4. Boyle T., Bradley C., Chalk P., Jones R., Pickard P. Using Blended Learning to Improve Student Success Rates in Learning to Program. Journal of Educational Media, 2003, no. $28(2-3)$, pp. 165-178. DOI: 10.1080/ 1358165032000153160

5. Chandra V., Fisher D.L. Students' Perceptions of a Blended Webbased Learning Environment. Learning Environments Research, 2009, no. 12 (1), pp. 31-44. DOI: 10.1007/ s10984-008-9051-6

6. Deegan D., Wims P., Pettit T. The Potential of Blended Learning in Agricultural Education of Ireland. International Journal of Agricultural Science, Research and Technology in Extension and Education Systems, 2015, no. 5 (1), pp. 53-64.

7. Gal'skova N.D. Sovremennaya metodika obucheniya inostrannym yazykam [Modern Technique of Training in Foreign Languages Teaching]. Moscow, Arkti-Glossa Publ., 2000. $165 \mathrm{p}$.
8. Gilbert J., Flores-Zambada R. Development and Implementation of a "Blended" Teaching Course Environment. Journal of Online Learning and Teaching, 2011, no. 7 (2), pp. 244-260.

9. Glazunova I.A. [Formation of a Foreign Communicative Competence by Means of Project Method as One of the Interactive Method of Teaching Foreign Languages in a Nonlinguistic University]. Molodoy uchenyiy, 2015, no. 15 (2), pp. 21-23. (in Russ.)

10. Gogolev N.E., Glukhareva M.R., Sabaraykin S.V., Ivanov Y.V. [Features of Organization of Scientific Activity of Future Specialists in the Sphere of Physical Culture and Sport]. Theory and Practice of Physical Cultury, 2015, no. 10, pp. 9-10. (in Russ.)

11. Golub G.B., Perelygina E.A., Churakova O.V., Kogan E.Ya. Metod proektov - tehnologiya kompetentnostno-orientirovannogo obrazovaniya [The Project Method - the Technology of the Competence-Based Approach]. Samara, Uchebnaya literatura Publ., Fedorov Publ., 2006. $176 \mathrm{p}$.

12. Gomes T., Panchoo P. Teaching Climate Change Through Blended Learning: A case study in a Private Secondary School in Mauritius. Proceedings of the IEEE International Conference on Computing, Communication and Security (ICCCS), 2015, pp.1-5. DOI: 10.1109/CCCS.2015.7374179

13. González Ramos M.L. R., Sánchez Seijo Y., Alcaide Guardado Y., Vázquez Vega M.J., Arteaga Valdés B., Cece González L. The Behavior of Scientific Publications. Revista Cubana De Educacion Medica Superior, no. 29 (3), pp. 483-495.

14. Holley D, Dobson C. Encouraging Student Engagement in a Blended Learning Environment: the Use of Contemporary Learning Spaces. Learning, Media and Technology, 2008, no. 33 (2), pp. 139-150. DOI: 10.1080/ 17439880802097683

15. Hughes G. Using Blended Learning to Increase Learner Support and Improve Retention. Teaching in Higher Education, 2007, no. 12 (3), pp. 349-363. DOI: 10.1080/13562510701278690

16. Knight S. E., Van Wyk J. M., Mahomed S. Teaching Research: A Programme to Develop Research Capacity in Undergraduate Medical Students at the University of KwaZuluNatal, South Africa. BMC Medical Education, vol. 16, no. 1. DOI: 10.1186/s12909-016-0567-7 
17. Korotkova E.G., Kolegova I.A. [On the Notion of Scientific Professional Project]. Sbornik materialov Mezhdunarodnoy nauchno-prakticheskoy konferentsii 1-2 oktyabrya 2015 goda "Universitet XXI veka v sisteme nepreryivnogo obrazovaniya" [Compilation of Reports From International Scientific and Practical Conference Oct 1-2. "XXI Century University in the System of Continuing Education"]. Chelyabinsk, South Ural St. Univ. Publ., 2015, pp. 31-35. (in Russ.)

18. Korotkova E.G., Kolegova I.A. Special Aspects of Student's Communication Competence in their Work on Professionaly Oriented Research and Busihess Scientific Project in a Foreign Language. Bulletin of the South Ural state University. Ser. Education. Educational sciences, 2015, vol. 7, no. 4, pp. 52-59. (in Russ.) DOI: 10.14529/ped150408

19. Kotjurova M.P. Stilistika nauchnoj rechi: uchebnoe posobie dlya studentov uchrezhdenij vyssh. prof. obr. [Scientific Speech Stylistics: Study Book for Students of the Institutions of Higher Education]. Moscow, Akademiya Publ., 2010. 240 p.

20. Kulikovskaya I.E., Abdulmanova L.V., Reznichenko A.V. Foreign Languages in the Educational Space of Southern Federal University of Russia. Review of European Studies, 2015, vol. 7, no. 6 , pp. 162-169. DOI: 10.5539/res.v7n6p162

21. Kuz'menkova Yu. B. Prezentatsiya nauchnyh proektov na angliyskom yazyke. Kniga dlya prepodavatelya: uchebnoe posobie dlya vuzoz [Presentation of Scientific Projects in English. Teacher's Book: Textbook for Universities]. 3nd ed. Moscow, MGU Publ., 2012. 138 p.

22. Lopatina O.V., Borisov A.M., Leyfa I.I., Galimzyanova I.I., Yatsevich L.P., Demyanenko M.A., Masalimova A.R. Role of Foreign Language Teacher Shaping Students' Research Skills. Asian Social Science, 2015, vol. 11, no. 4, pp. 135-140. DOI: 10.5539/ass.v11n4p135

23. López-pérez M.V., Pérez-López M.C., Rodríguez-Ariza L. Blended Learning in Higher Education: Students' Perceptions and their
Relation to Outcomes. Computers and Education, 2011, no. 56 (3), pp. 818-826. DOI: 10.1016/j.compedu.2010.10.023

24. Mazur V.V. Students' Participation in the Scientific Activities of a University. European Science Review, 2014, no. 11-12, pp. 42-46.

25. Proekt povysheniya konkurentosposobnosti vedushchikh rosseyskikh universitetov sredi vedushchikh Mirovykh nauchno-obrazovatel'nykh tsentrov. Ministerstvo obrazovaniya i nauki Rossiyskoy Federatsii [The project to Increase the Competitiveness of Leading Russian Universities Among the World's Leading Research and Educational Centers. Ministry of Education and Science of the Russian Federation]. Available at: http://5top100.ru/about/more-about/ (accessed 22.12.2018).

26. Serikov G.N. [Humanity Based Interpretation of Lecturer's Professional Competences]. Bulletin of the South Ural State University. Ser. Education. Educational sciences, 2009, no. 31 (164), pp. 29-35. (in Russ.)

27. Stockwell B.R., Stockwell M.S., Cennamo M., Jiang E. Blended Learning Improves. Science Education. Cell, 2015, no. 162 (5), pp. 933-936. DOI: 10.1016/j.cell.2015.08.009

28. Volchenkova K.N. Angliyskiy yazyk dlya issledovateley: Mezhdunarodnye konferentsii: uchebnik dlya povysheniya akademicheskoy mobil'nosti magistrantov, aspirantov i professorskoprepodavatel'skogo sostava [English for Researchers: International Conferences: Study Book for Increasing Academic Mobility of Master, Phd Students and Academic Staff]. Chelyabinsk, South Ural St. Univ. Publ., 2017. 87 p.

29. Yarullin I. F., Bushmeleva N. A., Tsyrkun I. I. The Research Competence Development of Students Trained in Mathematical Direction. International Electronic Journal of Mathematics Education, 2015, vol. 10, no. 3, pp. 137-146.

30. Yu M., Wu Y. J., Alhalabi W., Kao H., Wu W. Research Gate: An Effective Altmetric Indicator For Active Researchers. Computers in Human Behavior, 2016, no. 55, pp. 1001-1006. DOI: 10.1016/j.chb.2015.11.007

Received 21 January 2019 


\title{
ТЕСТИРОВАНИЕ МОДЕЛИ ФОРМИРОВАНИЯ И РАЗВИТИЯ КОМПЕТЕНЦИИ ПРОФЕССИОНАЛЬНОГО ОБЩЕНИЯ СТУДЕНТОВ В РАМКАХ РАБОТЫ НАД НАУЧНЫМ ПРОФЕССИОНАЛЬНЫМ ПРОЕКТОМ В УСЛОВИЯХ СМЕШАННОГО ОБУЧЕНИЯ
}

\author{
Е.Г. Короткова, И.А. Колегова \\ Южно-Уральский государственный университет, г. Челябинск, Россия
}

\begin{abstract}
В статье рассматривается вопрос развития компетенции профессионального общения студентов в рамках научного профессионального проекта. Необходимость данного исследования обусловлена законом РФ «Об образовании в Российской Федерации», который говорит об использовании в учебном процессе онлайн-курсов и смешанного обучения. Развитие компетенции профессионального общения у студентов при подготовке научных профессиональных проектов в условиях смешанного обучения недостаточно изучено. Вследствие этого цель проводимого исследования заключается в тестировании модели развития компетенции профессионального общения у студентов, которую авторы предложили в ходе своего долгосрочного исследования. В эксперименте принимали участие 350 студентов Южно-Уральского государственного университета, 2 лектора, 5 кандидатов наук и 2 профессора. Студенты были поделены на 4 группы: 2 экспериментальные и 2 контрольные. Для оценки компетенции профессионального общения была представлена специальная шкала с тремя уровнями: низкий, средний, продвинутый. Результаты эксперимента показали, что студенты в группах, где была внедрена представленная модель, показали качественно более высокий уровень владения компетенцией профессионального общения. Было доказано, что представленная модель, направленная на повышение научной активности студентов, может быть использована в образовательном процессе университета преподавателями специальных дисциплин и иностранного языка в рамках смешанного обучения.

Ключевые слова: смешанное обучение, компетенция профессионального общения студентов, научный профессиональный проект, онлайн-курсы.
\end{abstract}

\section{Лuтература}

1. Aspden, L. Making the Connection in a Blended Learning Environment / L. Aspden, P. Helm // Educational Media International. - 2004. - No. 41 (3). - P. 245-252.

2. Барышникова, Е.Н. Речевая культура молодого специалиста: учеб. пособие / Е.Н. Барышникова, Е.В. Клепач, Н.А. Красс. - М.: Флинта. Наука, 2005. - 224 с.

3. Blended learning in adult education: towards a definition of blended learning / R. Boelens, S. Van Laer, B. DeWever, J. Elen. - https://biblio.ugent.be/publication/6905076 (дата обращения: 12.12.2018).

4. Using blended learning to improve student success rates in learning to program / T. Boyle, C. Bradley, P. Chalk et al. // Journal of Educational Media. - 2003. - No. 28 (2-3). - P. 165-178.

5. Chandra, $V$. Students' perceptions of a blended webbased learning environment / V. Chandra, D.L. Fisher // Learning Environments Research. - 2009. - No. 12 (1). - P. 31-44.

6. Deegan, D. The potential of Blended Learning in Agricultural Education of Ireland / D. Deegan, P. Wims, T. Pettit // International Journal of Agricultural Science, Research and Technology in Extension and Education Systems. - 2015. - No. 5 (1). - P. 53-64.

7. Гальскова, Н.Д. Современная методика обучения иностранным языкам / Н.Д. Гальскова. М.: Аркти-Глосса, 2000. - 165 c.

8. Gilbert, J. Development and implementation of a "Blended" teaching course environment J. Gilbert, R. Flores-Zambada // Journal of Online Learning and Teaching. - 2011. - No. 7 (2). P. 244-260. 
9. Глазунова, И.А. Формирование иноязычной коммуникативной компетенциии с помощцью проектного метода как одного из интерактивных методов обучения иностранным языкам в неязыковом университете / И.А. Глазунова // Молодой ученый. - 2015. - №. 15 (2). - C. $21-23$.

10. Особенности организации научной деятельности будущчих специалистов сферы физической культуры и спорта / Н.Е. Гоголев, М.Р. Глухарева, С.В. Сабарайкин, Ю.В. Иванов // Теория и практика физ. культуры. - 2015. - № 10. - С. 9-10.

11. Голуб, Г.Б. Метод проектов - технология компетентностно-ориентированного образования / Г.Б. Голуб, Е.А. Перельгина, О.В. Чуракова; под ред. Е.Я. Когана. - Самара: Изд-во «Учебная литература»: Издат. дом «Федоров», 2006. - 176 c.

12. Gomes, T. Teaching Climate Change Through Blended Learning: A case study in a Private Secondary School in Mauritius / T. Gomes, P. Panchoo // Proceedings of the IEEE International Conference on Computing, Communication and Security (ICCCS). - 2015. - P. 1-5.

13. The behavior of scientific publications / M.L.R. González Ramos, Y. Sánchez Seijo, Y. Alcaide Guardado et al. // Revista Cubana De Educacion Medica Superior. - No. 29 (3). - P. 483-495.

14. Holley, D. Encouraging student engagement in a blended learning environment: the use of contemporary learning spaces / D. Holley, C. Dobson // Learning, Media and Technology. - 2008. No. 33 (2). - P. 139-150.

15. Hughes, G. Using blended learning to increase learner support and improve retention / G. Hughes // Teaching in Higher Education. - 2007. - No. 12 (3). - P. 349-363. DOI: /abs/10.1080/ 13562510701278690

16. Knight, S. E.Teaching research: A programme to develop research capacity in undergraduate medical students at the university of KwaZulu-Natal, South Africa / S.E. Knight, J.M. Van Wyk, S. Mahomed // BMC Medical Education. - Vol. 16, no. 1.

17. Короткова, Е.Г. К понятию научного профессионально-делового проекта / Е.Г. Короткова, И.А. Колегова // Сборник материалов международной научно-практической конференции 1-2 октября 2015 года «Университет ХХІ века в системе непрерывного образования. - Челябинск: Издат. иентр ЮУрГУ. - 2015. - С. 31-35.

18. Короткова, Е.Г. Особенности содержания понятия компетенции профессионального общения студента при работе над научным профессионально-деловым проектом на иностранном языке / Е.Г. Короткова, И.А. Колегова // Вестник ЮУрГУ. Серия «Образование. Педагогические науки». - 2015. - T. 7, № 4. - С. 52-60.

19. Котюрова, М.П. Стилистика научной речи: учеб. пособие для студентов учреждений высш. проф. образования / М.П. Котюрова. - М.: Издат. ичентр «Академия», 2010. - 240 с.

20. Kulikovskaya, I.E. Foreign languages in the educational space of southern federal university of Russia / I.E. Kulikovskaya, L.V. Abdulmanova, A.V. Reznichenko // Review of European Studies. 2015. - Vol. 7. - No. 6. - P. 162-169.

21. Кузьменкова, Ю.Б. Презентация научных проектов на английском языке. Книга для преподавателя: учеб. пособие для вузов / Ю.Б. Кузьменкова. - 3-е изд. - М.: Изд-во МГУ, 2012. $138 c$.

22. Role of foreign language teacher shaping students' research skills / O.V. Lopatina, A.M. Borisov, I.I. Leyfa et al. // Asian Social Science. - 2015. - Vol. 11, no. 4. - P. 135-140.

23. López-pérez, M.V. Blended learning in higher education: students' perceptions and their relation to outcomes / M.V. López-pérez, M.C. Pérez-López, L. Rodríguez-Ariza // Computers and Education. - 2011. - No. 56 (3). - P. 818-826.

24. Mazur, V.V. Students' participation in the scientific activities of a University / V.V. Mazur // European Science Review. - 2014. - No. 11-12. - P. 42-46.

25. Проект повышения конкурентоспособности ведущуих российских университетов среди ведущих научно-образовательных изентров. Министерство образования и науки Российской Федерачиии. - http://5top100.ru/about/more-about/ (дата обращения: 25.12.2018).

26. Сериков, Г.Н. Гуманно ориентированная интерпретация профессиональньх компетенций педагогов / Г.Н.Сериков // Вестник ЮУрГУ. Серия "Образование. Педагогические науки». 2009. - № 31 (164). - C. 29-35. 


\section{Теория и методика профессионального образования}

27. Blended Learning Improves / B.R. Stockwell, M.S. Stockwell, M. Cennamo, E. Jiang // Improves Science Education. Cell. - 2015. - No. 162 (5). - P. 933-936.

28. Волченкова, К.Н. Английский язык для исследователей: Международные конференции: учеб. для повышения академ. мобильности магистрантов, аспирантов и профессор.-преподават. состава / К.Н. Волченкова. - Челябинск: Издат. центр ЮУрГУ, 2017. - 87 с.

29. Yarullin, I. F. The research competence development of students trained in mathematical direction / I.F. Yarullin, N.A. Bushmeleva, I.I. Tsyrkun // International Electronic Journal of Mathematics Education. - 2015. - Vol. 10, no. 3. - P. 137-146.

30. Research Gate: An effective altmetric indicator for active researchers / M. Yu, Y.J. Wu, W. Alhalabi et al. // Computers in Human Behavior. - 2016. - No. 55. - P. 1001-1006.

Короткова Екатерина Геннадьевна, кандидат педагогических наук, доцент кафедры иностранных языков факультета лингвистики, Южно-Уральский государственный университет, г. Челябинск, korotkovaeg@susu.ru.

Колегова Ирина Александровна, кандидат педагогических наук, доцент кафедры иностранных языков факультета лингвистики, Южно-Уральский государственный университет, г. Челябинск, kolegovaia@susu.ru.

Поступила в редакцию 21 января 2019 г.

\section{ОБРАЗЕЦ ЦИТИРОВАНИЯ}

Korotkova, E.G. Testing a Model of Developing Students' Professional Communication Competence within the Framework of a Scientific Professional Project In Foreign Language in a Blended Learning Environment / E.G. Korotkova, I.A. Kolegova // Вестник ЮУрГУ. Серия «Образование. Педагогические науки». - 2019. - Т. 11, № 2. C. 91-100. DOI: 10.14529/ped190209

\section{FOR CITATION}

Korotkova E.G., Kolegova I.A. Testing a Model of Developing Students' Professional Communication Competence within the Framework of a Scientific Professional Project in Foreign Language in a Blended Learning Environment. Bulletin of the South Ural State University. Ser. Education. Educational Sciences. 2019, vol. 11, no. 2, pp. 91-100. DOI: 10.14529/ped190209 